\title{
A microtechnique for measuring red cell osmotic fragility of infants
}

\author{
RICHARD G. RYALL, ANDREW J. CHITTLEBOROUGH, AND ANNE KANE \\ From the Department of Haematology, Flinders Medical Centre, Bedford Park, South Australia 5042
}

SUMMARY Chloramphenicol( $D$-threo-2-dichloroacetamido-1- $p$-nitrophenylpropane-1, 3-diol) added to blood samples did not alter the observed shift in the red cell osmotic fragility curves as the samples were aged in vitro for 24 hours at $37^{\circ} \mathrm{C}$. Nor was the normal rate of loss of 2,3-diphosphoglycerate, ATP, or glutathione from the red cells affected by the presence of chloramphenicol over the same period. Consequently, this bacteriostatic agent can be added to blood samples taken under nonsterile conditions, such as from the heel of an infant, in order to preserve them from the effects of microbial contamination. In this way red cell osmotic fragility results can be obtained on non-sterile samples after their incubation at $37^{\circ} \mathrm{C}$ for 24 hours. A miniaturisation of the standard osmotic fragility procedure is described, which allows results to be produced from the small, non-sterile samples obtained by heel-prick of infants.

The osmotic fragility test of red blood cells is well established as a screening procedure in the diagnosis of red cell membrane abnormalities (Whitby and Hynes, 1935; Dacie and Vaughan, 1938). Its application in the diagnosis of hereditary spherocytosis and other haemolytic disorders is well documented (Dacie, 1960). It is of particular value in paediatric laboratory medicine where the early diagnosis of hereditary spherocytosis in the offspring of affected patients is important in their clinical management.

The interpretation of results in these cases is greatly helped by repeating the osmotic fragility measurements after incubating a sterile blood sample in vitro at $37^{\circ} \mathrm{C}$ for 24 hours (Selwyn and Dacie, 1954). In some cases red cells from a patient with hereditary spherocytosis will show an abnormal shift in the osmotic fragility curve only after such treatment, this being a reflection of the excessive loss of membrane lipid from affected cells (Reed and Swisher, 1966; Jacob, 1967) and their higher metabolic rate (Jacob, 1965).

A laboratory problem encountered when producing osmotic fragility results on infant patients is that many paediatricians are reluctant to venepuncture these patients and prefer to obtain samples by heel-prick. Such samples are generally of smaller volume than required for standard osmotic fragility measurements and are not sufficiently free of contamination to be incubated at $37^{\circ} \mathrm{C}$ for 24 hours without extensive denaturation.

Received for publication 30 January 1978
The following work was performed to show that the standard procedure for measuring red cell osmotic fragility (Dacie and Lewis, 1975) could be adapted to cater for microsamples, and that the bacteriostatic agent, chloramphenicol (CAP), could be used to maintain blood samples free from the effects of bacterial contamination without detriment to the red cells.

\section{Material and methods}

BUFFERED SODIUM CHLORIDE SOLUTIONS

The currently available protocols (eg, Dacie and Lewis, 1975) were modified since dilution of phosphate buffers with distilled water results in lowered solution $\mathrm{pH}$ values. The following solutions were prepared in which buffered saline was diluted with dilute phosphate buffer, $\mathrm{pH} 7 \cdot 40$.

\section{Solution $A$}

Phosphate buffer $11 \cdot 2$ mmoles/1, pH 7.40. Sodium dihydrogen phosphate dihydrate, $\mathrm{NaH}_{2} \mathrm{PO}_{4} .2 \mathrm{H}_{2} \mathrm{O}$, $3.50 \mathrm{~g}$ was dissolved in approximately $1700 \mathrm{ml}$ deionised water, and the $\mathrm{pH}$ of the resulting solution was adjusted to $7 \cdot 40$ with $0 \cdot 1$ mole/1 sodium hydroxide. The solution was made up to 21 , final adjustment of $\mathrm{pH}$ was made, and the osmolality was measured. An osmolality of approximately 33 mmoles/kg was observed, corresponding to $0.1 \%$ $\mathrm{w} / \mathrm{v}$ sodium chloride. 


\section{Solution $B$}

Sodium chloride, $9.0 \mathrm{~g}$, was dissolved in $600 \mathrm{ml}$ of solution $\mathrm{A}$ and the $\mathrm{pH}$ was adjusted to $7 \cdot 40$. The solution was made up to 1 litre with solution $A$, and its osmolality was measured. A value of approximately $315 \mathrm{mmoles} / \mathrm{kg}$ was observed, corresponding to $0.95 \% \mathrm{w} / \mathrm{v}$ sodium chloride.

\section{Working solutions}

Dilutions of solution B with solution A were prepared as required. The osmolality of individual solutions was calculated from:

Solution osmolality $=$

$\left(O s_{B}-O s_{A}\right) \frac{V_{B}}{V_{A}+V_{B}}+O s_{A} \ldots$ (1)

where $O s_{A}$ and $O s_{B}$ are the solution osmolalities and $V_{A}$ and $V_{B}$ are the volumes of solutions $A$ and $B$ mixed. All concentrations were originally expressed in osmolalities and later converted to the more traditional 'equivalent $\% \mathrm{NaCl}$ ' by the conversion 33 $\mathrm{mmoles} / \mathrm{kg}=0.1 \% \mathrm{w} / \mathrm{v} \mathrm{NaCl}$.

\section{CHLORAMPHENICOL (CAP)}

Forty milligrams chloramphenicol (Chloromycetin, Parke Davis and Company, Sydney) was dissolved in $4.0 \mathrm{ml}$ acetone and made up to $10 \mathrm{ml}$ with deionised water.

\section{ANALYSIS OF METABOLITES}

Red cell 2,3-diphosphoglycerate (DPG) was measured by the method of Nygaard and Rörth (1969), which was modified and available as a commercial kit (Calbiochem).

Whole blood ATP was also measured using commercial kit reagents (Calbiochem) based on the method of Kornberg (1955).

Red cell glutathione (GSH) was measured by the method of Beutler et al. (1963).

Red cell lysates for the assay of metabolites were prepared from whole blood filtered through cellulose according to the procedure of Beutler (1975). The filtered red cells were washed twice with iced saline and lysed in disodium-EDTA, 2.5 mmoles $/ 1, \mathrm{pH} 7 \cdot 00$. Samples of lysate were taken for analysis of GSH immediately on preparation; the remaining lysate was stored at $-70^{\circ} \mathrm{C}$ until required for analysis of DPG.

\section{BLOOD SAMPLES}

Blood samples were obtained from adults by venepuncture and divided into two parts. One part was defibrinated and handled under sterile conditions; the other was heparinised with 25 IU lithium heparin (preservative-free) per $\mathrm{ml}$ blood and treated with CAP solution, $5 \mu \mathrm{l}$ for every $200 \mu$ l blood. Blood samples of 100-200 $\mu \mathrm{l}$ were taken from infants by heel-prick into heparinised capillary tubes and treated with $5 \mu$ l CAP on receipt in the laboratory. Haemolysates for metabolite analyses were prepared, and osmotic fragility curves were measured on all samples within one hour of sampling. Samples containing CAP and sterile, defibrinated samples were also placed in an incubator at $37^{\circ} \mathrm{C}$ for 24 hours after which the measurements were repeated.

\section{OSMOTIC FRAGILITY MEASUREMENTS}

A minimum of $100 \mu \mathrm{l}$ blood is required. A series of buffered salt solutions of osmolalities ranging from 33 to $315 \mathrm{mmoles} / \mathrm{kg}$ were prepared by mixing solutions A and B in different proportions. Solution osmolalities were calculated using equation (1). Three millilitres of each solution was pipetted into a disposable cuvette $(1 \mathrm{~cm}$ light path $\times 1 \mathrm{~cm} \times 4.5 \mathrm{~cm}$, Ratiolab cat. 1101) followed by $2 \mu$ l blood. The mixtures were shaken and allowed to stand for 30 minutes at $20^{\circ} \mathrm{C}$, and the remaining intact red cells were then centrifuged out of suspension at $1200 \mathrm{~g}$ for two minutes. The absorbance of the supernant fluid in each cuvette was read in a Unicam SP 1750 spectrophotometer at $415 \mathrm{~nm}$ without decanting, using solution B as blank.

\section{Results}

It was found that the standard method of osmotic fragility measurement (Dacie and Lewis, 1975) and the current method gave identical results for the same sample at one hour and 24 hours after sampling. Patients included normal adults and infants, and adults and infants with hereditary spherocytosis. A minor difference was observed in the osmotic fragility curves of capillary and venous samples taken from the same individual. Heparinised capillary samples maintained with CAP showed a small increase in median corpuscular fragility of 10-15 mmoles $/ \mathrm{kg}(0.03-0.05 \% \mathrm{NaCl})$ when compared with the corresponding venous sample after 24 hours. The fragility curves were identical at one hour after sampling (Figure).

The combined effect of heparin with CAP on the concentrations of some major red cell metabolites was also insignificant. Table 1 lists the findings. No major disturbance of the red cell metabolism was obvious from these results. It is possible that heparinised samples maintained with CAP lost marginally less ATP and GSH than defibrinated sterile samples on incubation at $37^{\circ} \mathrm{C}$ for 24 hours (Table 1). However, these differences were slight and had no effect on the observed mean corpuscular fragility, nor on the overall shape of the fragility curve.

Table 2 gives the normal values for the osmotic 


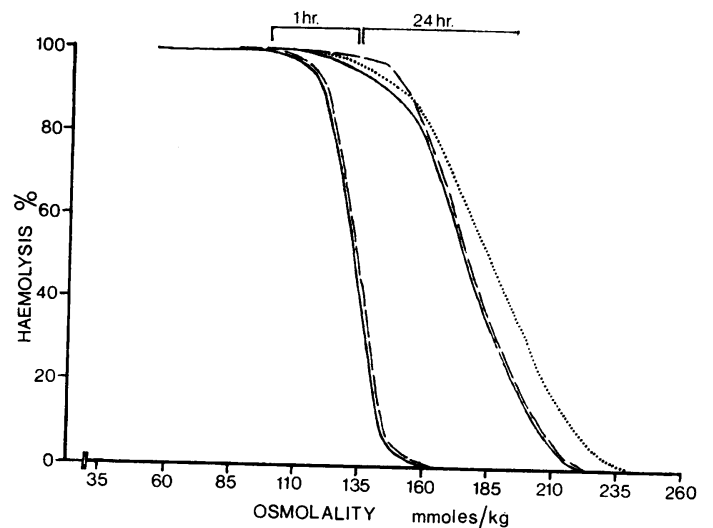

Figure Red cell osmotic fragility curves obtained from a single, normal adult at one hour and 24 hours after sampling:- venous blood, sterile, defibrinated, analysed according to Dacie and Lewis (1975); - venous blood, heparinised $+C A P$, analysed by the described micromethod; $\cdots \ldots \ldots$ capillary blood from a finger-prick, heparinised $+C A P$, analysed by the described micromethod. The curve for the capillary sample at one hour after sampling was superimposable on the venous blood curves and is not shown for clarity.

fragility curves of infants and adults derived in this study. During the derivation of these normal values, 22 healthy infants of ages 1,3 , and 5 days were studied. No separation of results was made on the basis of patient's age, nor was any trend in results obvious over this time span. Four patients of ABO groups potentially incompatible with those of their mothers were included in this normal range, and their osmotic fragility curves fell within the range established for the remaining infant patients. Osmotic fragility curves on infants did, however, show an osmotically resistant portion of the red cell population when compared with adult samples, and a wider range of osmotic fragility over the whole population (Danon et al., 1970; Luzzatto et al., 1970). However, it must be noted that in this study adult samples were obtained by venepuncture whereas infant samples were capillary samples.

\section{Discussion}

The described work followed from the practical problem of sample treatment for the estimation of post-incubation red cell osmotic fragility in blood samples taken under non-sterile conditions. By far the largest group of samples falling into this category are those taken by heel-prick from infants. These samples are generally of small volume and are certainly not sterile. The standard method of osmotic fragility measurement (Dacie and Lewis, 1975) was modified in two ways to overcome these two problems.

Firstly, a microtechnique was devised whereby only $2 \mu \mathrm{l}$ blood was required per measurement. The usual heel-prick sample of $100-200 \mu \mathrm{l}$ was therefore ample to produce two osmotic fragility curves. This diminution of sample volume is possible if measurement of lysis is made at $415 \mathrm{~nm}$. This peak in the visible spectrum of heme is far more intense than the more commonly used peak at $540 \mathrm{~nm}$. Either wavelength can be used without the results being affected.

The second problem, that of preserving non-sterile blood samples against the effects of microbial contamination, was overcome by adding CAP to the samples on their receipt in the laboratory. CAP was chosen as the bacteriostatic agent for testing because its metabolic effects are known to be directed primarily against mitochondrial synthesis functions.

Table 1 Effect of heparin and CAP on concentration of red cell metabolites after incubation at $37^{\circ} \mathrm{C}$

\begin{tabular}{|c|c|c|c|c|c|c|c|c|c|}
\hline \multirow[t]{2}{*}{ Patients } & \multirow[t]{2}{*}{$\begin{array}{l}\text { Incubation } \\
\text { (hours) }\end{array}$} & \multicolumn{2}{|c|}{$G S H(\mu$ moles/l RBC) } & \multicolumn{2}{|c|}{$D P G($ mmoles $/ l R B C)$} & \multicolumn{2}{|c|}{$A T P(\mu m o l e s / l$ blood) } & \multicolumn{2}{|c|}{$\begin{array}{r}\text { Mean corpuscular fragility } \\
\text { (mmoles } / k g)\end{array}$} \\
\hline & & $\begin{array}{l}\text { Sterile } \\
\text { defibrinated }\end{array}$ & $\begin{array}{l}\text { Heparin } \\
\text { and } C A P\end{array}$ & $\begin{array}{l}\text { Sterile } \\
\text { defibrinated }\end{array}$ & $\begin{array}{l}\text { Heparin } \\
\text { and } C A P\end{array}$ & $\begin{array}{l}\text { Sterile } \\
\text { defibrinated }\end{array}$ & $\begin{array}{l}\text { Heparin } \\
\text { and } C A P\end{array}$ & $\begin{array}{l}\text { Sterile } \\
\text { defibrinated }\end{array}$ & $\begin{array}{l}\text { Heparin } \\
\text { and } C A P\end{array}$ \\
\hline Normal $\mathbf{M}$ & $\begin{array}{r}1 \\
24\end{array}$ & $\begin{array}{r}2123 \\
926\end{array}$ & $\begin{array}{l}1982 \\
1148\end{array}$ & $\begin{array}{l}4 \cdot 5 \\
1 \cdot 2\end{array}$ & $\begin{array}{l}4 \cdot 8 \\
1 \cdot 1\end{array}$ & $\begin{array}{r}746 \\
43\end{array}$ & $\begin{array}{r}688 \\
85\end{array}$ & $\begin{array}{l}138 \\
180\end{array}$ & 138 \\
\hline Normal M & 1 & 3022 & 2946 & $6 \cdot 7$ & $6 \cdot 7$ & 439 & $\begin{array}{r}85 \\
569\end{array}$ & $\begin{array}{l}180 \\
140\end{array}$ & $\begin{array}{l}174 \\
140\end{array}$ \\
\hline Hereditary & 24 & 535 & 685 & $1 \cdot 7$ & $1 \cdot 8$ & 7 & 36 & 174 & 168 \\
\hline $\begin{array}{l}\text { spherocytosis F } \\
\text { Pyruvate kinase }\end{array}$ & $\begin{array}{r}1 \\
24\end{array}$ & $\begin{array}{r}2483 \\
576\end{array}$ & $\begin{array}{r}2379 \\
901\end{array}$ & $\begin{array}{l}5 \cdot 5 \\
1 \cdot 0\end{array}$ & $\begin{array}{l}5 \cdot 6 \\
0 \cdot 8\end{array}$ & $\begin{array}{r}552 \\
60\end{array}$ & $\begin{array}{r}569 \\
89\end{array}$ & $\begin{array}{l}159 \\
212\end{array}$ & $\begin{array}{l}159 \\
218\end{array}$ \\
\hline $\begin{array}{c}\text { Pyruvate kinase } \\
\text { deficient* M }\end{array}$ & $\begin{array}{r}1 \\
24\end{array}$ & $\begin{array}{l}3862 \\
2388\end{array}$ & $\begin{array}{l}3793 \\
2889\end{array}$ & $12 \cdot 4$ & $13 \cdot 5$ & $\begin{array}{r}405 \\
72\end{array}$ & $\begin{array}{l}468 \\
119\end{array}$ & $\begin{array}{l}128 \\
142\end{array}$ & $\begin{array}{l}128 \\
148\end{array}$ \\
\hline $\begin{array}{l}\text { Pyruvate kinase } \\
\text { mutant } F\end{array}$ & $\begin{array}{r}1 \\
24\end{array}$ & $\begin{array}{l}3566 \\
1997\end{array}$ & $\begin{array}{l}3463 \\
2444\end{array}$ & $\begin{array}{l}6.0 \\
2.0\end{array}$ & $\begin{array}{l}5 \cdot 8 \\
1 \cdot 0\end{array}$ & $\begin{array}{r}293 \\
17\end{array}$ & $\begin{array}{r}320 \\
20\end{array}$ & $\begin{array}{l}128 \\
160\end{array}$ & $\begin{array}{l}124 \\
160\end{array}$ \\
\hline
\end{tabular}

* $14 \%$ reticulocytes.

Conversion: SI units to traditional-ATP: $1 \mu \mathrm{mole} / 1 \approx 0.059 \mathrm{mg} / \mathrm{dl}$. Salt concentrations: $1 \mathrm{mmole} / \mathrm{kg} \approx 0.0303 \mathrm{~g} \mathrm{NaCl} / \mathrm{l}$. 
Table 2 Normal values for osmotic fragility curves obtained on heel-prick samples from 22 infants (up to 5 days old) and venous samples from 19 adults, before and after incubation of samples at $37^{\circ} \mathrm{C}$ for 24 hours. All samples were heparinised blood treated with CAP.

\begin{tabular}{|c|c|c|c|c|c|}
\hline \multicolumn{2}{|c|}{ Salt concentration } & \multicolumn{2}{|l|}{$\begin{array}{l}\text { Infants } \\
\% \text { lysis }\end{array}$} & \multicolumn{2}{|l|}{$\begin{array}{l}\text { Adults } \\
\% \text { lysis }\end{array}$} \\
\hline mmoles/kg & Equivalent $\mathrm{NaCl}(\mathrm{g} / \mathrm{l})$ & 1 hour & 24 hours & 1 hour & 24 hours \\
\hline $\begin{array}{r}45 \\
60 \\
75 \\
90 \\
105 \\
120 \\
135 \\
150 \\
165 \\
180 \\
195 \\
210 \\
225 \\
240 \\
255 \\
270 \\
285\end{array}$ & $\begin{array}{l}1 \cdot 4 \\
1 \cdot 8 \\
2 \cdot 3 \\
2 \cdot 7 \\
3 \cdot 2 \\
3 \cdot 6 \\
4 \cdot 1 \\
4 \cdot 5 \\
5 \cdot 0 \\
5 \cdot 5 \\
5 \cdot 9 \\
6 \cdot 4 \\
6 \cdot 8 \\
7 \cdot 3 \\
7 \cdot 7 \\
8 \cdot 2 \\
8 \cdot 6\end{array}$ & 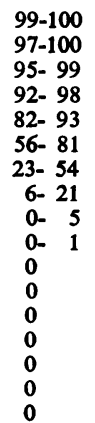 & $\begin{array}{c}99-100 \\
98-100 \\
97-100 \\
96-100 \\
94-100 \\
87-99 \\
67-95 \\
46-86 \\
27-68 \\
13-46 \\
5-28 \\
2-17 \\
0-11 \\
0-7 \\
0-44 \\
0-2 \\
0\end{array}$ & 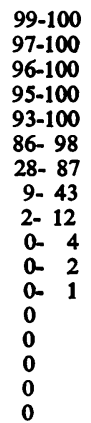 & 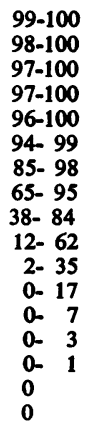 \\
\hline
\end{tabular}

Mitochondrial protein synthesis is inhibited by CAP (Kurtz, 1974). $\Delta$-Aminolevulinic acid synthetase activity is altered in reticulocyte (Rosenberg and Marcus, 1974) and bone marrow mitochondria (Bottomley and Smithee, 1971) leading to impairment of heme synthesis (Beck et al., 1972). Yunis (1973) observed ultrastructural damage to bone marrow mitochondria as a result of CAP therapy in patients. None of these effects, however, should apply to mature red cells since these have no mitochondria. CAP could be expected to produce no serious disruption of their metabolism. The results shown in Table 1 would support this contention.

More direct effects of CAP on red cell membranes, such as those disruptions caused by certain antineoplastic drugs (Ben-Basaat et al., 1972; Schrier et al., 1974), have not been reported. It is known that membrane renewal depends upon active glycolysis within the cells (Ben-Basaat et al., 1972) and that the type of membrane internalisations produced, for example, by primaquine, have a large effect on red cell osmotic fragility (George et al., 1966).

Similar effects of CAP on red cell membranes, however, were not obvious in the current work. Sterile, defibrinated blood samples and heparinised samples treated with CAP were found to have closely similar ATP content and osmotic fragility curves, both before and after incubation at $37^{\circ} \mathrm{C}$ for 24 hours.

It is concluded, therefore, that CAP can be used routinely to preserve non-sterile blood samples free from the effects of bacterial action without detriment to the red cells, in normal patients and in patients with hereditary spherocytosis, so that post-incubation osmotic fragility measurements can be performed.
We thank Dr R. S. Seshadri and Professor A. A. Morley, both of the Department of Haematology, Flinders Medical Centre, for valuable discussions during this work.

\section{References}

Beck, E. A., Buchler, F., Armentrout, S. A., and Lüdin, H. (1972). Early hematological abnormalities associated with chloramphenicol therapy. Helvetica Medica Acta, 36, 295-306.

Ben-Basaat, I., Bensch, K. G., and Schrier, S. L. (1972). Drug-induced erythrocyte membrane internalisation. Journal of Clintcal Investigation, 51, 1833-1844.

Beutler, E. (1975). Red Cell Metabolism, 2nd edition, pp. 8-11. Grune and Stratton, New York.

Beutler, E., Duron, O., and Kelly, B. M. (1963). Improved method for the determination of blood glutathione. Journal of Laboratory and Clinical Medicine, 61, 882890.

Bottomley, S. S., and Smithee, G. A. (1971). Stimulation of bone marrow $\Delta$-aminolevulinic acid synthetase by chloramphenicol in vitro. Federation Proceedings, 30, 1230 (abstract).

Dacie, J. V. (1960). The Haemolytic Anaemias, part 1, 2nd edition, pp. 36-42. J. and A. Churchill, London.

Dacie, J. V., and Lewis, S. M. (1975). Practical Haematology, 5th edition, pp. 202-208. Churchill Livingstone, Edinburgh.

Dacie, J. V., and Vaughan, J. M. (1938). The fragility of the red blood cells: its measurement and significance. Journal of Pathology and Bacteriology, 46, 341-356.

Danon, G., Kleimann, A., and Danon, D. (1970). The osmotic fragility and density distribution of erythrocytes in the newborn. Acta Haematologica, 43, 242-247.

George, J. N., O'Brien, R. L., Pollack, S., and Crosby, W. B. (1966). Studies of in vitro primaquine haemolysis: substrate requirement for erythrocyte membrane 
damage. Journal of Clinical Investigation, 45, 1280-1289.

Jacob, H. S. (1965). Hereditary spherocytosis: a disease of the red cell membrane. Seminars in Haematology, 2, 139-166.

Jacob, H. S. (1967). Membrane lipid depletion in hyperpermeable red blood cells: Its role in the genesis of spherocytes in hereditary spherocytosis. Journal of Clinical Investigation, 46, 2083-2094.

Kornberg, A. (1955). Methods in Enzymology, vol. 2, edited by S. P. Colowick and N. O. Kaplan, pp. 497501. Academic Press, New York.

Kurtz, D. J. (1974). Fidelity of protein synthesis with chicken embryo mitochondrial and cytoplasmic ribosomes. Biochemistry, 13, 572-577.

Luzzatto, L., Esan, G. J. F., and Ogiemudia, S. E. (1970). The osmotic fragility of red cells in newborns and infants. Acta Haematologica, 43, 248-256.

Nygaard, S. F., and Rörth, M. (1969). An enzymatic assay of 2,3-diphosphogylcerate in blood. Scandinavian Journal of Clinical and Laboratory Investigation, 24, 399-403.

Reed, C. F., and Swisher, S. N. (1966). Erythrocyte lipid loss in hereditary spherocytosis. Journal of Clinical Investigation, 45, 777-781.
Rosenberg, A., and Marcus, D. (1974). Effect of chloramphenicol on reticulocyte $\triangle$-aminolaevulinic acid synthetase in rabbits. British Journal of Haematology, 26, 79-83.

Schrier, S. L., Ben-Basaat, J., Bensch, K., Seeger, M., and Junga, I. (1974). Erythrocyte membrane vacuole formation in hereditary spherocytosis. British Journal of Haematology, 26, 59-69.

Selwyn, J. G., and Dacie, J. V. (1954). Autohemolysis and other changes resulting from the incubation in vitro of red cells from patients with congenital hemolytic anaemia. Blood, 9, 414-438.

Whitby, L. E. H., and Hynes, M. (1935). The quantitative estimation of the fragility of the red corpuscles. Journal of Pathology and Bacteriology, 40, 219-230.

Yunis, A. A. (1973). Chloramphenicol toxicity. Blood Disorders Due to Drugs and Other Agents, edited by R. H. Girdwood, pp. 107-126. Excerpta Medica, Amsterdam.

Requests for reprints to: Dr R. G. Ryall, Department of Haematology, Flinders Medical Centre, Bedford Park, South Australia 5042. 